Sains Malaysiana 47(1)(2018): 35-49

http://dx.doi.org/10.17576/jsm-2018-4701-05

\title{
Removal of Heavy Metals from Wastewater using Date Palm as a Biosorbent: A Comparative Review
}

(Penyingkiran Logam Berat dari Air Kumbahan menggunakan Kurma sebagai Satu Bahan Bioserap: Satu Kajian Perbandingan)

\author{
M. SHAFIQ, A.A. ALAZBA \& M.T. AMIN*
}

\begin{abstract}
The drawbacks associated with activated carbon, mainly cost, have resulted in the continuing search for inexpensive adsorbents easily and abundantly available as waste materials. The current review presents the results of using different forms of date palm (DP) waste as low-cost biosorbents, highlighting effects of contact time, $p H$, the dose and size of the adsorbent particles, initial metal concentrations and the effects of pre-treatment on the adsorption efficiency of copper $\left(\mathrm{Cu}^{2+}\right)$. The results of studies using the raw DP trunk fiber suggested the equilibrium time was approximately $2 \mathrm{~h}$, with a significantly high removal of $\mathrm{Cu}^{2+}$ during the initial 1 h at acidic $\mathrm{pH}$ values of 5-6, which indicated the interference of $H^{+}$ions with metal ions at low pH values. The raw DP trunk fiber was tested with initial particle sizes of 75-251 $\mu \mathrm{m}$ and adsorbent dosages in the range of 0.4-5.0 $\mathrm{g} \mathrm{L}^{-1}$. The best adsorption efficiency was obtained at the smallest particle size and the maximum dosage. The use of different initial $\mathrm{Cu}^{2+}$ concentrations resulted in a $10 \%$ decrease in removal, but the adsorption capacity was increased three-fold with an initial concentration of 20-100 $\mathrm{mg} \mathrm{L}^{-1}$. A significantly higher removal efficiency of $\mathrm{Cu}^{2+}$ was achieved using the modified DP waste than with the raw trunk fiber for all experimental parameters and operational conditions owing to the increased functional groups on the modified adsorbents. The reviewed literature confirmed the efficiency of DP waste for the adsorption of heavy metals, but the use of the raw or even modified $D P$ waste for the large-scale treatment of wastewater is still a concern owing to the cost effectiveness, availability and requirement for DP waste on a massive scale. Further research for physical modifications of the raw DP waste that employs cost-effective techniques, such as using the DP waste in the form of dehydrated carbon and media filters are required.
\end{abstract}

Keywords: Adsorption; date palm waste; heavy metal; large-scale; wastewater treatment

\section{ABSTRAK}

Kelemahan yang dikaitkan dengan karbon, terutamanya kos, telah mengakibatkan pencarian berterusan untuk bahan cerap murah sedia ada dengan banyak sebagai bahan buangan. Kajian ini membentangkan keputusan daripada penggunaan sisa buangan kurma (DP) dalam bentuk yang berbeza sebagai bahan cerap berkos rendah, menonjolkan kesan hubungan masa, $\mathrm{pH}$, dos dan saiz zarah bahan cerap, kepekatan logam pemula dan kesan pra rawatan ke atas kecekapan penjerapan tembaga $\left(\mathrm{Cu}^{2+}\right)$. Keputusan kajian menggunakan serabut batang DP mentah mencadangkan masa keseimbangan adalah kira-kira 2 jam dengan penyingkiran tinggi $\mathrm{Cu}^{2+}$ semasa 1 jam pemula pada nilai asid pH 5-6, yang menunjukkan gangguan ion $H^{+}$dengan logam ion pada nilai $p H$ rendah. Serabut batang DP mentah diuji dengan saiz zarah pemula daripada 75-251 $\mathrm{\mu m}$ dan dos bahan cerap dalam lingkungan 0.4-5.0 $\mathrm{g} \mathrm{L}^{-1}$. Kecekapan penjerapan terbaik telah diperoleh pada saiz zarah terkecil dan dos maksimum. Penggunaan pemula $\mathrm{Cu}^{2}+$ berbeza kepekatan mengakibatkan pengurangan $10 \%$ penyingkiran, tetapi keupayaan penjerapan meningkat tiga kali ganda dengan kepekatan pemula 20-100 $\mathrm{mg} \mathrm{L}^{-1}$. Kecekapan penyingkiran yang jauh lebih tinggi daripada $\mathrm{Cu}^{2+}$ telah dicapai menggunakan sisa DP terubah suai berbanding dengan serabut batang mentah untuk semua parameter kajian dan operasi keadaan disebabkan peningkatan kumpulan fungsian pada bahan cerap terubah suai. Kajian kepustakaan mengesahkan kecekapan sisa kumbahan DP bagi penjerapan logam berat, tetapi penggunaan sisa rawatan mentah atau DP terubah suai untuk rawatan pada skala besar masih menjadi kebimbangan kepada keberkesanan kos, ketersediaan dan keperluan bagi sisa kumbahan DP pada skala besar-besaran. Kajian lanjutan bagi pengubahsuaian fizikal sisa kumbahan DP yang menggunakan teknik keberkesanan kos seperti meng gunakan sisa kumbahan DP dalam bentuk penapis dehidrasi karbon dan media adalah diperlukan.

Kata kunci: Logam berat; penjerapan; rawatan sisa air; sisa kurma; skala besar

\section{INTRODUCTION}

Freshwater is the chief constituent of the planet and is essential to the survival of all living organisms. It is a source of food, health and energy. Many countries in the world are facing water crises owing to the absence of permanent rivers or lakes and very little rainfall, especially 
in arid regions such as the Kingdom of Saudi Arabia (KSA). Water is scarce and is becoming increasingly more valuable in parallel with the rapid growth of the global population (Lim et al. 2014). Additionally, the increased consumption of water in industry, agriculture and households has resulted in the daily addition of billions of gallons of wastewater to be freshwater reserves. According to UN estimates, the total annual amount of produced wastewater is approximately $1500 \mathrm{~km}^{3}$, which is six times more water than exists in all the rivers of the world (UN WWAP 2003). Consequently, many fresh water reservoirs are becoming unsuitable for daily usage owing to the untreated disposal of wastewater (Renge et al. 2012; Singh \& Kaushal 2013).

Wastewater from industries, such as metal plating, pulp and paper production, mining operations, ceramics production, tanneries and radiator manufacturing, smelting, alloy manufacturing, battery manufacturing (Ahmaruzzaman 2011), textile and dyes, is a major source of the various kinds of harmful effluents, which is increasing in line with rapid industrial growth (Alshabanat et al. 2013). The number of total pollutants in water, including organic and inorganic pollutants, is thought to be over 700. However, metallic pollutants are among the most dangerous owing to their toxicity and non- biodegradable nature. These characteristics also make them highly persistent in the environment. Among these metals, cadmium, platinum, copper, lead, chromium, mercury, arsenic and antimony are of major concern (Brusick 1993; Dich et al. 1997; Hossain et al. 2014; Moore \& Ramamoorthy 1984). These heavy metals can cause adverse health effects, such as diarrhea, gastrointestinal disorders, stomatitis, tumors, hemoglobinuria, ataxia, paralysis, vomiting and convulsions. As each of these heavy metals exhibits a specific toxicity profile (Chatterjee et al. 2010), the effective recovery of heavy metals from waste streams is considered important. Major importance has been attached to the treatment of industrial wastewater effluent, as local and international authorities (Table 1) require that industrial wastewater should be treated to meet a set standard before discharge into water bodies.

Several advanced techniques exist for the reduction of the environmental impact of industrial wastewater containing heavy metal ions, such as reverse osmosis (Gupta et al. 2012), advanced oxidation (Oller et al. 2011), ion exchange (Da, browski et al. 2004), solvent extraction (Hall et al. 1990), membrane filtration processes (Blöcher et al. 2003; Mavrov et al. 2006; Paez-Hernandez et al. 2005), GAC/O 3 oxidation (Qian

TABLE 1. Allowable limits of heavy metals in drinking and wastewater by international organizations

\begin{tabular}{|c|c|c|c|c|}
\hline $\begin{array}{l}\text { Heavy } \\
\text { metals }\end{array}$ & Adverse health effects & $\begin{array}{l}\text { Allowed limits } \\
\mathrm{WHO}^{*} \mathrm{EPA}^{* *} \\
\quad\left(\mathrm{mg} \mathrm{L}^{-1}\right)\end{array}$ & Sources of contamination & References \\
\hline Copper & $\begin{array}{l}\text { Gastrointestinal (GI) distress, GI irritation, } \\
\text { liver and kidney damage }\end{array}$ & $1.0-1.3$ & $\begin{array}{l}\text { Corrosion of household, plumbing, } \\
\text { erosion of natural deposits }\end{array}$ & (Bilal et al. 2013) \\
\hline Lead & $\begin{array}{l}\text { Delayed development in children, both mental } \\
\text { and physical, anemia, vomiting, kidney } \\
\text { damage, high blood pressure }\end{array}$ & $0.005-0.015$ & $\begin{array}{l}\text { Corrosion of house hold plumbing } \\
\text { systems, erosion }\end{array}$ & $\begin{array}{l}\text { (WHO 2011; Zahra } \\
\text { 2012) }\end{array}$ \\
\hline Cadmium & Kidney damage, lung cancer, proteinuria & 0.005 & $\begin{array}{l}\text { Pipes, erosion of metal refineries, } \\
\text { waste batteries, paints }\end{array}$ & $\begin{array}{l}\text { (Purkayastha et al. } \\
\text { 2014) }\end{array}$ \\
\hline Arsenic & $\begin{array}{l}\text { Cancer, skin damage, circulatory system } \\
\text { problems }\end{array}$ & 0.01 & $\begin{array}{l}\text { Erosion of natural deposits, runoff } \\
\text { from orchards, runoff from glass and } \\
\text { electronics production waste }\end{array}$ & (Shakoor et al. 2016) \\
\hline Chromium & Allergic dermatitis, hemolysis, renal failure & $0.05-0.25$ & Steel industry, pulp mills, erosion & (Yadav et al. 2015) \\
\hline Antimony & $\begin{array}{l}\text { Increased blood cholesterol, decreased blood } \\
\text { sugar }\end{array}$ & 0.006 & $\begin{array}{l}\text { Petroleum refineries, fire retardants, } \\
\text { ceramics, electronics, solder }\end{array}$ & (WHO 2011) \\
\hline Mercury & Hypersensitivity, fever, vomiting, neurasthenia & 0.002 & $\begin{array}{l}\text { Erosion of natural deposits, discharge } \\
\text { from refineries and factories, runoff } \\
\text { from landfills, croplands }\end{array}$ & (WHO 2011) \\
\hline Selenium & $\begin{array}{l}\text { Hair and finger nail loss, red skin, numbness } \\
\text { in fingers and toes, caustic burns, circulatory } \\
\text { problems }\end{array}$ & $0.01-0.05$ & $\begin{array}{l}\text { Petroleum refineries, erosion, } \\
\text { discharge from mines }\end{array}$ & (WHO 2011) \\
\hline Zinc & $\begin{array}{l}\text { Corrosive to skin and eye, zinc pox, sweet taste, } \\
\text { throat dryness, cough, weakness, generalized } \\
\text { aching, chills, fever, nausea, vomiting }\end{array}$ & 5 & $\begin{array}{l}\text { Electroplating industry, galvanized } \\
\text { metal surfaces, motor oil and } \\
\text { hydraulic fluid, tire dust }\end{array}$ & $\begin{array}{l}\text { (Kanawade \& } \\
\text { Gaikwad 2011) }\end{array}$ \\
\hline Beryllium & Intestinal problems & 0.004 & $\begin{array}{l}\text { Metal refineries, coal-burning } \\
\text { factories, discharge from electrical, } \\
\text { aerospace, and defense industries }\end{array}$ & (WHO 2011) \\
\hline
\end{tabular}

* World Health Organization, ** USA Environmental Protection Agency 
et al. 2013), Fenton process (Zhang et al. 2012), lime softening (Varga et al. 2013), coagulation/flocculation (Amuda et al. 2006), electrochemical processes (Ahmad et al. 2012), electrocoagulation (Balasubramanian et al. 2009; Ratna Kumar et al. 2004), chitosan graphene oxide nanocomposites (Shahzad et al. 2017) and chemical precipitation (Rathinam et al. 2010). These treatment methods have some limitations, which include highenergy requirements, production of oxidation by-products, regeneration requirements during ion exchange, bulk toxic sludge generation in flocculation/coagulation methods, short half-life in ozonation and membrane fouling during the filtration process. Furthermore, the treatments are also ineffective when the metal ion concentration in aqueous solution is in the range from 10-100 $\mathrm{mg} \mathrm{L}^{-1}$ (Bulut \& Tez 2007). Thus, there has been an increase in demand for technologies that are sustainable in terms of economy, efficiency, energy and environment.

Wastewater treatment through adsorption is economically and technically favorable. The efficiency of the adsorption relies on the capability of the adsorbent to adsorb metal ions from the solutions onto its surfaces. Activated carbon (AC) has been suggested as a suitable adsorbent owing to its high adsorption capacity, small particle sizes, maximum internal surface area and active free valences. In spite of this, it could not be used as an adsorbent for large-scale water treatment owing to its high cost of production. Moreover, the regeneration of AC is difficult, as it involves the use of costly chemicals and it regeneration also has limited viability on a commercial scale.

The drawbacks associated with $\mathrm{AC}$ have resulted in the growth of research into the development of low-cost alternatives that are easily and abundantly available as waste materials. In this study, the results of heavy metals removal from wastewater using different forms of date palm (DP) waste as low-cost biosorbents are reviewed, with a focus on the effects of the different reaction parameters that affect the adsorption efficiency. In addition, results from the author's recent studies (Amin et al. 2016) are also presented and compared to highlight the effects of contact time, $\mathrm{pH}$, the dose and size of the adsorbent particles, initial metal concentrations and the effect of pre-treatment on the adsorption efficiency of selected copper $\left(\mathrm{Cu}^{2+}\right)$.

\section{ADSORBENT TYPES AND ADSORPTION PROCESS}

To fulfill the industrial demands for a cheap and efficient low cost biomaterial, several materials have been studied as potential adsorbents. These adsorbents are classified into two types: conventional and non-conventional, as shown in Figure 1. Conventional adsorbents have been used on limited scale, including alumina, zeolite, AC, silica gel and bauxite (Baral et al. 2007; Gupta et al. 2013; Izhar et al. 2014; Jacques et al. 2007; Kim et al. 2013; Sankararamakrishnan et al. 2014; Wang \& Peng 2010; Zwain et al.2014); among the non-conventional, the most frequently used is agricultural waste (Table 2).

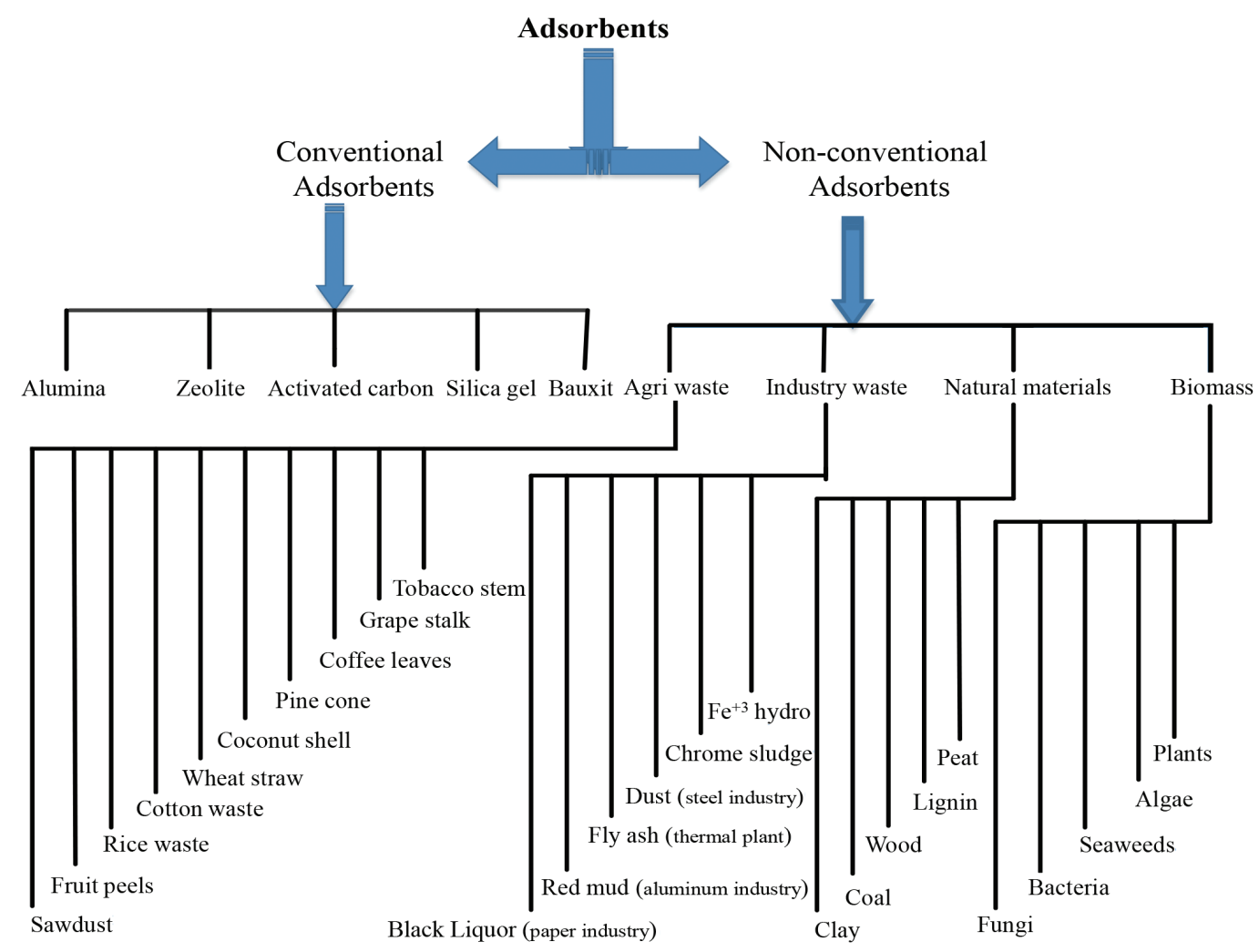

FIGURE 1. Adsorbent types and classifications 
TABLE 2. Non-conventional agricultural waste used as adsorbents for heavy metals

\begin{tabular}{|c|c|c|}
\hline Type & Waste material & Reference \\
\hline Agricultural Waste & $\begin{array}{l}\text { Sawdust } \\
\text { Fruit peels } \\
\text { Rice husks } \\
\text { Cotton wastes } \\
\text { Wheat straws } \\
\text { Coconut shell } \\
\text { Pine cone } \\
\text { Coffee leaves } \\
\text { Grapes stalks } \\
\text { Tobacco stem }\end{array}$ & $\begin{array}{l}\text { (Akunwa et al. 2014; Putra et al. 2014) } \\
\text { (Ajmal et al. 2000; Liang et al. 2009; Marin et al. 2010; Sha et al. 2009) } \\
\text { (Lattuada et al. 2014) } \\
\text { (Riaz et al. 2009) } \\
\text { (Tan \& Xiao 2009) } \\
\text { (Kamari et al. 2014) } \\
\text { (Momcilovic et al. 2011) } \\
\text { (Saka et al. 2012; Tan 1985) } \\
\text { (Bsoul et al. 2014) } \\
\text { (Li et al. 2008) }\end{array}$ \\
\hline Industry Waste & $\begin{array}{l}\text { Black liquor } \\
\text { Red mud } \\
\text { Fly ash } \\
\text { Steel industry dust } \\
\text { Chrome sludge } \\
\mathrm{Fe}^{3+} \text { hydro }\end{array}$ & $\begin{array}{l}\text { (Srivastava et al. 1994) } \\
\text { (Sahu et al. 2013) } \\
\text { (Banerjee et al. 2003; Shyam et al. 2013; Sočo \& Kalembkiewicz 2013) } \\
\text { (Bhattacharya et al. 2006) } \\
\text { (Lee et al. 1996) } \\
\text { (Namasivayam \& Senthilkumar 1999) }\end{array}$ \\
\hline Natural Materials & $\begin{array}{l}\text { Clay } \\
\text { Coal } \\
\text { Wood } \\
\text { Lignin } \\
\text { Peat }\end{array}$ & $\begin{array}{l}\text { (Olaofe et al. 2015) } \\
\text { (Mohan \& Gandhimathi 2009) } \\
\text { (Sciban et al. 2007) } \\
\text { (Srivastava et al. 1994) } \\
\text { (Ho et al. 2002) }\end{array}$ \\
\hline Biomass & $\begin{array}{l}\text { Fungi } \\
\text { Bacteria } \\
\text { Seaweed } \\
\text { Algae } \\
\text { Plants }\end{array}$ & $\begin{array}{l}\text { (Javaid et al. 2011) } \\
\text { (Li et al. 2013; Opeolu et al. 2010) } \\
\text { (Ahmady-Asbchin et al. 2009; Muhammad \& Nwaedozie 2012) } \\
\text { (He \& Chen 2014) } \\
\text { (Narain et al. 2011; Srivastav et al. 1993) }\end{array}$ \\
\hline
\end{tabular}

Adsorption is a mass transfer process that involves the accumulation of substances at the interface of two phases or a separation technique from which target elements of the liquid/fluid phase are shifted to the solid surface. Owing to its ease of operation and wide range of applications, adsorption is considered as a comprehensive water treatment and reclamation technique. It can also be applied for the removal of organic, inorganic, and biological pollutants with a removal efficiency of up to $99 \%$. Therefore, the technique has gained attention for the treatment of industrial wastewater, mainly owing to the low-cost and bulk availability of bio-adsorbents, metal selectivity, easy metal recovery, higher heavy metal uptake, and reuse (Ali 2010; Mandal 2014).

The technique is the result of attractive forces between adsorbed molecules and the solid surface. These attractive forces are weak Van der Waals forces, hydrogen bonding, and dipole-dipole interaction, which ensures successful desorption. It is independent of the electronic properties of the adsorbent and adsorbate molecules. Moreover, the physisorption can be mono or multilayer, a reversible process and it decreases with an increase in temperature. Commercial adsorbents rely on physical adsorption.

Electrostatic chemical bonding between the adsorbate and adsorbent occurs in a monolayer and is usually an irreversible process, which is site specific and dependent on the temperature increase. It involves an exchange of electrons between specific surface sites and solute molecules, which results in the formation of strong chemical bonds. Very high temperatures are required for desorption. The adsorption of organic molecules exhibits a large range of binding energies.

\section{DATE PALM AS AN EMERGING BIOMATERIAL}

The total number of DP trees in the world is approximately 120 million, cultivated on an area of 800000 ha distributed in 30 countries (Al-Kaabi et al. 2005; El-Juhany 2010). The analysis of the regional distribution (Table 3 ) indicated that approximately 60 million DP trees are found in Asia (e.g. Saudi Arabia, Bahrain, UAE, Iran, Iraq, Kuwait, Oman, Pakistan, Turkmenistan and Yemen) and approximately 32.5 million DP trees are found in Africa (Algeria, Egypt, Libya, Mali, Morocco, Mauritania and Niger). The total weight of DP waste produce in the world is 4.5 million tons (Barreveld 1993).A DP tree produces approximately $40 \mathrm{~kg}$ of burnable waste, including dried leaves, spathes, sheaths and petioles, annually (Mallaki \& Fatehi 2014).

\section{PROPERTIES OF DATE PALM FOR ADSORPTION}

DP is considered the best biosorbent for the removal of all types of effluent from industrial wastewater, but is particular effective for the removal of heavy metals. The properties that contribute to its efficacy are discussed below. 
TABLE 3. Annual productivity of date palm wastes in different countries (El-Juhany 2010)

\begin{tabular}{lccc}
\hline Countries & $\begin{array}{c}\text { Cultivation area } \\
(1000 \text { ha })\end{array}$ & $\begin{array}{c}\text { Total number of trees } \\
(\text { millions })\end{array}$ & $\begin{array}{c}\text { Waste produce annually } \\
(1000 \text { ton })\end{array}$ \\
\hline Iraq & 101 & 8 & 320 \\
Iran & 180 & 21 & 840 \\
Saudi Arabia & 155 & 12 & 480 \\
Algeria & 159 & 11 & 440 \\
Egypt & 45 & 12 & 482 \\
Libya & 25 & 2 & 80 \\
Pakistan & 90.1 & 4 & 160 \\
Morocco & 42 & 5.7 & 228 \\
UAE & 219 & 16 & 640 \\
Tunisia & 46 & 3 & 120 \\
Yemen & 10 & 4.5 & 180 \\
Oman & 32 & 2.6 & 96 \\
\hline
\end{tabular}

\section{HIGH HEAVY METAL REMOVAL CAPACITY}

Most of the studies showed that the heavy metal ion removal capacity of DP waste is higher than other natural waste materials owing to its chemical composition. DP fibers are lignocellulosic materials, which consist of three vital components: Cellulose (40-50\%), hemicellulose (20-35\%) and lignin (15-35\%) (Al-Kabbi et al. 2005). Lignin is the most important constituent and has complex chemical constituents within the DP waste material, as it is a three-dimensional polymer of phenyl propane units linked together by $\mathrm{C}-\mathrm{C}$ or $\mathrm{C}-\mathrm{O}-\mathrm{C}$ bonds. Thus, the elemental composition has a high carbon percentage (62 wt. \%) and a lower oxygen percentage (32 wt. \%). A larger number of carbon atoms is generally associated with a lower polarity and hence a greater potential for adsorption; also, lignin has great impact on the adsorption process owing to a large numbers of carbon atoms. For this reason, a lignocellulosic material is the preferred adsorbent for adsorption techniques (Barreveld 1993).

\section{SMALL ADSORBENT DOSAGE}

Many researchers have claimed that by using only a small amount of DP adsorbent, heavy metals and other pollutants can be removed more effectively in comparison with other natural low cost adsorbents. Yadav et al. (2015) reported that DP trunk fibers could remove up to $99.95 \%$ of chromate anions $\left(\mathrm{Cr}^{6+}\right)$ from a $100 \mathrm{mg} \mathrm{L}^{-1}$ solution by using a small adsorbent dosage of $1.2 \mathrm{~g} \mathrm{~L}^{-1}$.

\section{SHORT CONTACT TIME FOR EQUILIBRIUM}

It has been observed in the literature that DP required a short time to adsorb heavy metals from aqueous solution. Al-Ghamdi reported that DP trunk fiber had a very short equilibration time $(10 \mathrm{~min})$ for cadmium adsorption (Al-Ghamdi et al. 2013). Yadav et al. (2013) reported that in case of $\mathrm{Pb}^{2+}$, the adsorption process was fast and equilibrium was established within $120 \mathrm{~min}$. Hilal et al. (2012) reported an equilibrium time of $60 \mathrm{~min}$ in the case of copper and cadmium adsorption using date pits with activation and non-activation. The fast adsorption process supports the application in wastewater treatment facilities as the operating time to separate metal ions is low and the cost of the process can be minimized.

\section{BEST PRECURSOR FOR AC PREPARATION}

In the last decades, the adsorption systems involving AC has become popular in industrial-scale filtration processes (Ali 2010). It is currently the best available technology for the removal of organic and inorganic pollutants. Commercially available ACs is still expensive and cause different problems to the environment, such as the nonbiodegradable nature of silica gel. Therefore, researchers have attempted to develop AC from renewable sources that are widely available and economical in use. AC is defined by its properties and source and it can be produced from all fibrous organic materials having high carbon content. The ACs derived from these natural materials possesses a highly porous structure and large surface area $\left(600-2000 \mathrm{~m}^{2} \mathrm{~g}^{-1}\right)$ (Demirbas 2008). They have been found to adsorb a variety of contaminants, such as metals, dyes and phenols, which have been used effectively for the treatment of domestic and industrial wastewaters. DP wastes contain high amount of carbon (62 wt. \%). Thus, it is the best renewable source for AC production of water purification on an industrial scale (Yacob et al. 2013).

\section{EXAMPLES OF HEAVY METALS ADSORPTION USING DP WASTES}

DP waste has been used in various forms for different heavy metals removal from wastewater. The removal of $\mathrm{Pb}^{2+}$, for example, has been investigated by many researchers using DP trunk, DP leaves, DP leaves ash, and palm leaf base (the petiole). The adsorption of $\mathrm{Pb}^{2+}$ was studied in batch experiments by using different parameters, including the contact time, solution $\mathrm{pH}$, initial metal concentration, adsorbent dosage, particle sizes of the DP waste materials and temperature. It was concluded that the adsorption process was quick and the equilibrium was attained within 120 min (Yadav et al. 2013). The maximum removal efficiency of approximately $94-99 \%$ was achieved with the 
$\mathrm{pH}$ range of 4.5-5.8 in most of studies, which highlighted the good adsorption capacity of the solution at acidic $\mathrm{pH}$ (Al-Haidary et al. 2011; Boudrahem et al. 2011; Ghorbani et al. 2012). The optimum range of other parameters varies depending upon the reaction conditions in different studies, for example, the adsorbent dose (0.5-5 $\left.\mathrm{g} \mathrm{L}^{-1}\right)$ and initial $\mathrm{Pb}^{2+}$ concentration (10, 50 and $\left.103.5 \mathrm{mg} \mathrm{L}^{-1}\right)$. Other factors, such as the agitation speed and ionic strength of the aqueous solution, also exerted great effects on the adsorption process (Al-Haidary et al. 2011; Boudrahem et al.2011). In a study, the chemically treated date palm leave biosorbents were used for their ability to remove $\mathrm{Pb}^{2+}$ from aqueous solution and it was found that the removal of the investigated metal ions by AC increased with an increase in contact time and reached an equilibrium state within 3 h (Hikmat et al. 2014; Soliman et al. 2016).

Similarly, the adsorption of $\mathrm{Cd}^{2+}$ on to DP trunk fiber, AC derived from date stones and both the raw and chemically activated date pits was studied in batch tests of different parameters, as previously mentioned (Al-Ghamdi et al. 2013; Chaouch et al. 2013; Hilal et al. 2012). The efficiency of the chemically activated date pits showed a three-fold increase compared with the raw date stones in terms of $\mathrm{Cd}^{2+}$ adsorption capacity and the equilibrium time was achieved after $1 \mathrm{~h}$ (Hilal et al. 2012). The values of other influential parameters for maximum adsorption were identified as particle size, 100 microns; temperature, $34^{\circ} \mathrm{C}$; and mixing speed, $100-500 \mathrm{rpm}$ (Al-Ghamdi et al. 2013). Also, the application of DP waste in different other forms, for example, raw and treated DP leaves for the removal of zinc and silver ions, respectively, raw date pits for $\mathrm{Au}^{3+}$ removal and DP seed for chromium $\left(\mathrm{Cr}^{6+}\right)$ removal from aqueous solution, has been investigated in different studies (Al-Rub 2006; Al-Saidi 2013; El Nemr et al. 2008). The adsorption of zinc was found to be highly $\mathrm{pH}$ dependent and $90 \%$ of the adsorption was completed within approximately $10 \mathrm{~min}$ (Al-Rub 2006), while the same adsorption of $\mathrm{Au}^{+}{ }^{+}$was achieved with approximately 90 min of shaking in an aqueous medium (Al-Saidi 2013). The contact time required to attain the equilibrium was almost doubled, i.e. $180 \mathrm{~min}$ for $\mathrm{Cr}^{6+}$ and $100 \%$ removal of $\mathrm{Cr}^{6+}$ was attained using $4 \mathrm{~g} \mathrm{~L}^{-1}$ of carbon concentration, with a maximum adsorption capacity of $120 \mathrm{mg} \mathrm{g}^{-1}$ (El Nemr et al. 2008).

The adsorption of $\mathrm{Cu}^{2+}$ was also studied extensively using DP based low-cost biosorbents (date stones, palm-tree waste, DP leaves pretreated with sulfuric acid and chemically activated date pits) (Belala et al. 2011; Bouhamed et al. 2012; Hilal et al. 2012). A significant decrease in removal efficiency was observed with an increase in particle size and the adsorption process was deemed as endothermic, but was exothermic when using date stone and palm tree waste (Belala et al. 2011). The sorption of $\mathrm{Cu}^{2+}$ was rapid, with equilibrium reached within $120 \mathrm{~min}$ (Bouhamed et al. 2012). The maximum adsorption was observed at $\mathrm{pH} 5.8 \pm 0.5$ with activated date pits, which was five times more efficient than the raw date pits (Hilal et al. 2012). The authors have also studied the application of both the raw and modified DP waste to study and compare the adsorption of $\mathrm{Cu}^{2+}$ and the results are presented in the following sections (Amin et al. 2016).

\section{Major FaCtors AfFecting Heavy Metals REMOVAL EFFICIENCY}

A number of factors, including contact time, $\mathrm{pH}$, dose and size of the adsorbent, initial metal concentrations have been investigated for their influence on the extent of heavy metal adsorption, for example, in a study of $\mathrm{Cu}^{2+}$ that used DP in the raw and modified forms. For the raw DP waste, fibers were weaved and removed from the trunk of the tree and after washing, filtering, drying in the oven and crushing, different particle sizes of the raw DP waste were in the range 75-250 $\mu \mathrm{m}$ were used (Amin et al. 2016). For pre-treated DP waste, ethanol and $\mathrm{NaOH}$ were initially used, with the subsequent application of mercaptoacetic acid $\left(\mathrm{C}_{2} \mathrm{H}_{2} \mathrm{O}_{2} \mathrm{~S}\right)$ for the conversion of its abundant hydroxyl groups into mercapto groups, which have a high affinity for metal ions and subsequently improved the adsorption capacity.

\section{INTERNAL SURFACE AREA OF AN ADSORBENT AND PORE- SIZE DISTRIBUTION}

The specific surface area of the solid adsorbent is important, as the adsorptive capacity generally increases with an increase in specific surface area. The natural materials are available in bulk quantities and possess a large surface area and high cation exchange capacity, which are requisite properties of an adsorbent. Thus, a larger internal surface area results in a greater adsorption capacity. Authors have obtained the insight into the surfaces of the raw and modified DP trunk fibers and leaves, as shown in Figure 2. For the raw DP trunk fibers, as shown in Figure 2(a), rough asymmetric pores and cylinders were seen, which were considered to be composed of multicellular fibers bound together by lignin.

The adsorption capacity of the adsorbent depends upon the pore size distribution. Three types of pores can be distinguished: Macro pores, meso pores and micro pores (Table 4). The macro pores and meso pores are predominantly relevant for the mass transfer into the interior of the adsorbent particles, whereas the volume of the micro pores mainly determines the size of internal surface and therefore the adsorbent capacity. It is a rule that higher micro pore volume leads to the adsorbance of a larger amount of material.

\section{EFFECTS OF THE CONTACT TIME}

The determination of residence time is an important characteristic in the definition of the efficiency of an adsorbent (Krishnan \& Anirudhan 2003) and is controlled by processes, such as bulk diffusion, external mass transfer and chemical reaction (Ho et al.2002). The longer the time, the more complete the adsorption, but in some studies, it was concluded that a few adsorbents were able to adsorb contaminants within short time (Table 5). A shorter 

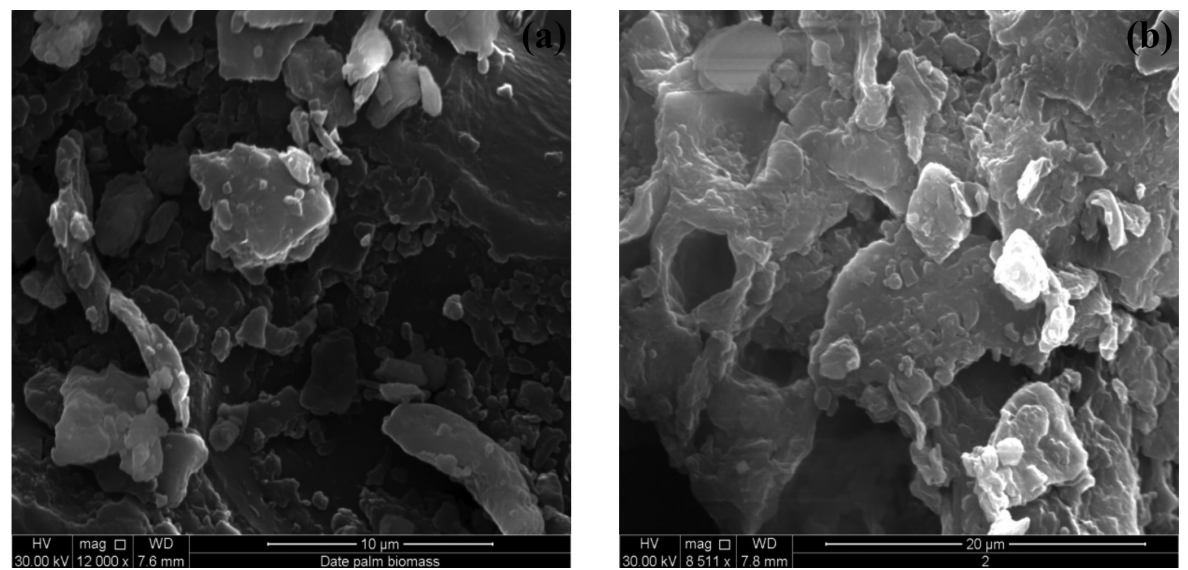

FIGURE 2. SEM images of the (a) raw DP trunk fiber and (b) treated DP leaves (Amin et al. 2016)

TABLE 4. Classification of pores according to the IUPAC*

\begin{tabular}{lc}
\hline Pore class & Range of pore radius \\
\hline Macro pores & $>25 \mathrm{~nm}$ \\
Meso pores & $1-25 \mathrm{~nm}$ \\
Micro pores & $<1 \mathrm{~nm}$ \\
\hline
\end{tabular}

*International Union of Pure and Applied Chemistry

TABLE 5. Effects of the contact time on the removal of different heavy metals using DP waste

\begin{tabular}{lcccl}
\hline \multicolumn{1}{c}{ Adsorbent } & Heavy metal & Contact time, min & Removal, \% & \multicolumn{1}{c}{ Reference } \\
\hline DP trunk fiber & $\mathrm{Cd}^{2+}$ & 10 & 51.1 & (Al-Ghamdi et al. 2013) \\
Palm fiber and petiole & $\mathrm{Pb}^{2+}$ & 30 and 40 & $98.4,96.5$ & (Hikmat et al. 2014) \\
Palm tree leaves & $\mathrm{Zn}$ & 10 & 90 & (Al-Rub 2006) \\
DP biomass & $\mathrm{Hg}$ & 180 & 92 & (Rajamohan et al. 2014) \\
DP pits & $\mathrm{Cr}$ & 120 & 65.89 & (Hamouche et al. 2015) \\
Palm tree leaves & $\mathrm{Pb}^{2+}$ & 180 & 98 & (Soliman et al. 2016) \\
\hline
\end{tabular}

absorption is more efficient material as the faster adsorption process enhanced the feasibility of the process to be applied in wastewater treatment facilities as the operating time to separate the contaminants is small. Consequently, the process cost can be minimized.

A recent study (Amin et al. 2016) also investigated the effects of contact time on heavy metal adsorption capacity and percentage removal from $50 \mathrm{mg} \mathrm{L}^{-1}$ of initial $\mathrm{Cu}^{2+}$ concentration using raw DP trunk fiber (Figure 3 ). The study concluded the time required to attain equilibrium was approximately $2 \mathrm{~h}$, with a significant removal of $\mathrm{Cu}^{2+}$ during the initial $1 \mathrm{~h}$. The rapid removal of the metal during the initial few minutes may be attributed to the uncovered surface area of the adsorbents and the dependency of the adsorption on the surface area (Qadeer \& Akhtar 2005).

\section{EFFECTS OF THE SOLUTION pH}

The $\mathrm{pH}$ has a large impact in governing the mechanism of the adsorption process (Areco \& Dos Santos Afonso 2010). In most previous studies, efficient adsorption takes place at acidic $\mathrm{pH}$ (Table 6), although it depends upon the

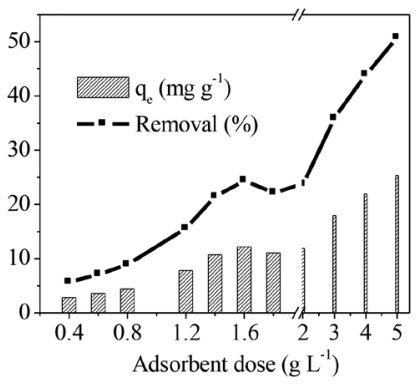

FIGURE 3. Effects of the contact time on the adsorption capacity and percentage removal of $\mathrm{Cu}^{2+}$

nature of the adsorbate and adsorbent. Furthermore, the degree of ionization of a species is affected by the $\mathrm{pH}$, for example, the presence of a weak acid or a weak base, which subsequently affected the adsorption.

The effects of the solution $\mathrm{pH}$ in the range from 2-6 on the adsorption capacity and percentage removal of $\mathrm{Cu}^{2+}$ by using the raw DP trunk fibers were investigated by authors in a recent study (Figure 4 ) with an initial $\mathrm{Cu}^{2+}$ 
TABLE 6. Effects of the solution on the percent removal of different heavy metals using DP waste

\begin{tabular}{lcccl}
\hline Adsorbent & Contaminant & $\mathrm{pH}$ & $\%$ Removal & \multicolumn{1}{c}{ Reference } \\
\hline AC from DP seed & $\mathrm{Cr}^{6+}$ & 2 & 100 & (El Nemr et al. 2008) \\
DP biomass & $\mathrm{Hg}^{+}$ & 7 & 92 & (Rajamohan et al. 2014) \\
Modified DP trunk & $\mathrm{Cr}^{6+}$ & 3.5 & 89.3 & (Yadav et al. 2015) \\
Xanthated DP trunk & $\mathrm{Pb}^{2+}$ & 5 & 99.4 & (Yadav et al. 2013) \\
\hline
\end{tabular}

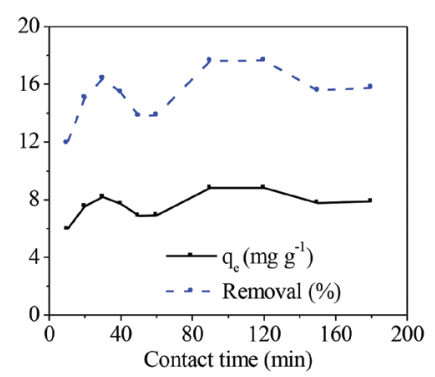

FIGURE 4. Effects of the solution pH on the adsorption capacity and percentage removal of $\mathrm{Cu}^{2+}$

concentration of $50 \mathrm{mg} \mathrm{L}^{-1}$ and an adsorbent dose of $1 \mathrm{~g} \mathrm{~L}^{-1}$ (Amin et al. 2016). Significantly high and low adsorption showed the interference of $\mathrm{H}^{+}$ions with metal ions and increased electrostatic repulsive interaction that resulted from low and high $\mathrm{pH}$ values, respectively (Chieng et al. 2015; El-Bindary et al. 2014).

\section{EFFECTS OF THE PARTICLE SIZE OF ADSORBENT}

The particle size of the adsorbent has great impact on the adsorption of heavy metals from wastewater, as smaller particle sizes reduce internal diffusional and mass transfer limitations to the penetration of the adsorbate, i.e. the equilibrium is more easily achieved and almost full adsorption capability can be attained. Larger molecules may be too large to enter small pores, which may reduce adsorption independently of other causes. When the particle size is increased, a longer interaction time is required to obtain similar results, as diffusion must occur through the aggregates. Recent findings of authors on the effects of different particle size of raw DP waste on the adsorption efficiency of $\mathrm{Cu}^{2+}$ are presented in Figure 5 (Amin et al. 2016).

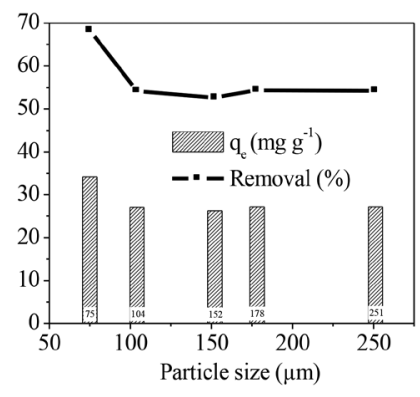

FIGURE 5. Effects of the particle size on the adsorption capacity and percentage removal of $\mathrm{Cu}^{2+}$

The raw DP waste of the trunk fiber with different initial particle sizes $(75-251 \mu \mathrm{m})$ was used and a higher removal of the studied heavy metal was seen with an adsorbent size of $75 \mu \mathrm{m}$ compared with the largest used particle size (251 $\mu \mathrm{m})$, which suggested that a greater surface area to metal ion ratio was achieved with smaller particles (Al-Ghouti et al. 2010).

\section{EFFECTS OF THE ADSORBENT DOSE}

The mass of the adsorbent has great impact on the adsorption process. An increase in the adsorbent dosage results in decreased adsorption capacity and increased removal percentage (Table 7). An important issue in the influence of adsorption capacity and economy of the process is adsorbent dosage. From economic perspective, it is very important to achieve maximum removal efficiency with minimum adsorbent dosage.

The effects of different initial adsorbent dosage in the range from $0.4-5.0 \mathrm{~g} \mathrm{~L}^{-1}$ (Amin et al. 2016) were also studied, as shown in Figure 6. Other constant parameters of batch experiments included the solution $\mathrm{pH}$ (5.0), initial metal concentration (50 $\left.\mathrm{mg} \mathrm{L}^{-1}\right)$ and contact time (150 min).

TABLE 7. Effects of the adsorbent dose on the percent removal of different heavy metals using DP waste

\begin{tabular}{lcccl}
\hline \multicolumn{1}{c}{ Adsorbent } & Contaminant & $\begin{array}{c}\text { Adsorbent dose } \\
\mathrm{g} \mathrm{L}^{-1}\end{array}$ & \% Removal & \multicolumn{1}{c}{ Reference } \\
\hline Xanthated DP trunk & $\mathrm{Pb}^{2+}$ & 5 & 99.4 & (Yadav et al. 2013) \\
Raw date pits & $\mathrm{Cu}^{2+}$ & 0.5 & 90 & (Hilal et al. 2012) \\
DP fiber (leaves) & $\mathrm{Cr}^{6+}$ & 5 & 98.7 & (Haleem \& Abdulgafoor 2010) \\
Palm fiber and petiole & $\mathrm{Pb}^{2+}$ & 0.5 & 88 & (Hikmat et al. 2014) \\
Raw date pits & $\mathrm{Cd}^{2+}$ & 0.5 & 65.7 & (Hilal et al. 2012) \\
DP leaves & $\mathrm{Pb}^{2+}$ & 1 & 94 & (Boudrahem et al. 2011) \\
Modified DP trunk & $\mathrm{Cr}^{6+}$ & 1.2 & 99.95 & (Yadav et al. 2015a) \\
DP leaf ash & $\mathrm{Pb}^{2+}$ & 0.5 & 99.72 & (Ghorbani et al. 2012) \\
\hline
\end{tabular}


The superior adsorption efficiency at maximum dose of $5 \mathrm{~g}$ $\mathrm{L}^{-1}$ to that at the lowest dosage of $0.4 \mathrm{~g} \mathrm{~L}^{-1}$ can be attributed to the larger surface area present on more binding sites (Aydın et al. 2008; Uzunoğlu et al. 2014).

\section{EFFECTS OF THE INITIAL METAL CONCENTRATION}

Generally, the adsorption capacity of any adsorbent increases with increasing metal concentration (Yadav et al. 2015) and reaches at maximum at a certain concentration. The effect of the initial metal concentration is mostly calculated in the sorption isotherm, which gives information regarding the maximum sorption capacity of a biosorbent. Most of the heavy metals can transfer from the aqueous solution to the biosorbent surface as a result of a driving force produced by initial concentration of analyte in aqueous solution (Amin et al. 2015). As the initial metal concentration increases, there are more metal oxyanions available for biosorption reaction in the solution (Ebrahimi et al. 2013). The percentage removal of the metal, however, decreases with increasing metal concentration. This may be attributable to the lack of sufficient surface area to accommodate excess metal available in the solution at lower concentrations and the saturation of adsorption sites at high concentrations (Ghorbani et al. 2012). Table 8 presents a summary of the effects of initial metal concentrations on adsorption efficiency in different selected studies.

The effects of initial $\mathrm{Cu}^{2+}$ concentration on the adsorption capacity and percentage removal by raw DP trunk fibers have been studied in detail (Amin et al . 2016) by using concentrations in the range from $20-100 \mathrm{mg} \mathrm{L}^{-1}$, as shown in Figure 7. Although the percentage removal was only decreased by approximately $10 \%(31 \%$ to $23 \%)$ at higher initial concentrations of the metal owing to the saturation of sorption sites at the adsorbent surface (Al-Homaidan et al. 2014; Putra et al. 2014), the capacity of the absorbed metal increased by almost three times with an increase in the initial concentration from 20 to $100 \mathrm{mg} \mathrm{L}^{-1}$.

\section{PRE-TREATMENT EFFECTS AND COMPARISON OF THE RAW AND MODIFIED DP WASTE}

The pretreatment or modification of raw or natural biosorbents, although potentially expensive, can be critical to enhance the adsorption capacity, control coloration and govern the release of organic materials in the water (Ali et al. 2013; Jiménez-Cedillo et al. 2013; Mohan \& Pittman 2007; Zhu et al. 2008). It can also be helpful for the enhancement of porosity and stability (Khosa et al.2013). There are two main methods for pretreatment of biosorbents: Physical or chemical. Physical pretreatment includes drying, grinding,
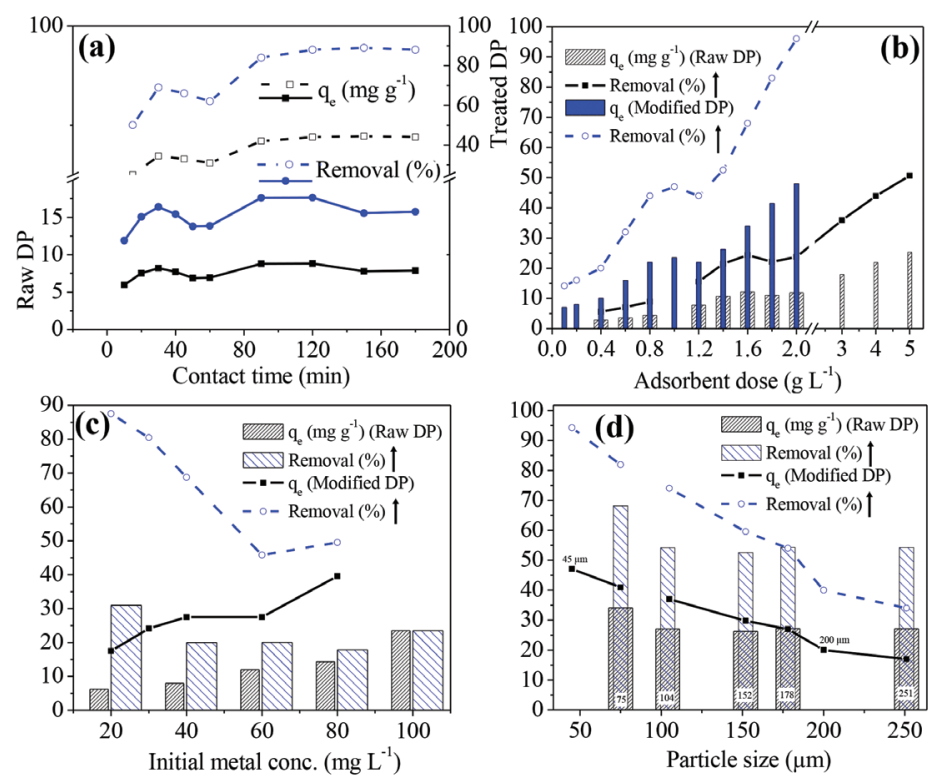

FIGURE 6. Effects of the adsorbent dose on the adsorption capacity and percentage removal of $\mathrm{Cu}^{2+}$

TABLE 8. Effects of the metal concentration on the percentage removal of different heavy metals using DP waste

\begin{tabular}{lcccl}
\hline \multicolumn{1}{c}{ Adsorbent } & Contaminant & $\begin{array}{c}\text { Initial metal conc., } \\
\mathrm{mg} \mathrm{L}^{-1}\end{array}$ & $\begin{array}{c}\% \\
\text { Removal }\end{array}$ & \multicolumn{1}{c}{ Reference } \\
\hline Algerian date stones AC & $\mathrm{Pb}^{2+}$ & 50 & 99.12 & (Chaouch et al. 2014) \\
Algerian date stones AC & $\mathrm{Cd}^{2+}$ & 50 & 42.86 & (Chaouch et al. 2013) \\
DP fiber (leaves) & $\mathrm{Cr}^{6+}$ & 25 & 95.2 & (Haleem \& Abdulgafoor 2010) \\
DP leaf ash & $\mathrm{Pb}^{2+}$ & 50 & 99.72 & (Ghorbani et al. 2012) \\
\hline
\end{tabular}




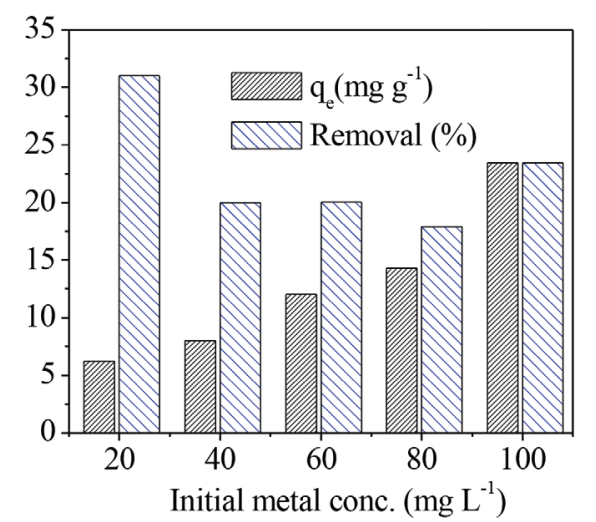

FIGURE 7. Effects of the initial metal concentrations on the adsorption capacity and percentage removal of $\mathrm{Cu}^{2+}$

cutting, thermal heating and steam activation, so it is easier, simple and less costly. However, it is not extensively used owing a low efficacy in the enhancement of heavy metal sorption on the biosorbent surface. In contrast, chemical modifications have been given priority because they efficiently increase the biosorbent stability and heavy metal sorption capacity (Park et al. 2010). Chemical modification can be categorized as pretreatment washing e.g. by acid (mercaptoacetic acid, sulfuric acid, nitric acid and hydrochloric acid), alkali $(\mathrm{NaOH}, \mathrm{KOH})$ and $\mathrm{Fe}$ salt or Fe oxide mineral coating (such as coating with ferric chloride, ferric nitrate, goethite and magnetite minerals) (Pehlivan et al. 2013). As stated earlier, results for treated DP waste have been compared with those for raw DP waste with regard to the adsorption capacity and the percentage removal of $\mathrm{Cu}^{2+}$, as shown in Figure 8.
A significantly higher removal efficiency of metal ions using the modified DP waste compared with the raw form was observed under all the experimental parameters and operational conditions. This was most likely owing to the increased functional groups on the modified adsorbents (Abia et al. 2004). As can be seen in Figure 8(b), an adsorbent dose of $1.4 \mathrm{~g} \mathrm{~L}^{-1}$ was required for the modified DP adsorbent compared with $5 \mathrm{~g} \mathrm{~L}^{-1}$ of the raw DP trunk fibers for the same removal efficiency of $\mathrm{Cu}^{2+}$, which reduced the cost of the raw materials by more than half. Similarly, the percentage removal of the $\mathrm{Cu}^{2+}$ WAS increased from approximately 30 to $90 \%$ for the lowest used initial metal concentration (20 $\mathrm{mg} \mathrm{L}^{-1}$, as shown in Figure 8(c)) when the raw DP waste with was modified with acidic pretreatment. The positive effects of pre-treatment are also obvious with respect to the particle size of the adsorbent when the removal efficiency was almost doubled at the smallest particle size of $45 \mu \mathrm{m}$ (Figure 8(d)).

\section{CONCLUSIONS AND PROSPECTS}

The reviewed literature and discussed results in this study show that the utilization of DP waste material for the adsorption of heavy metals is an efficient and common method of wastewater treatment. Studies have shown the effectiveness of the both raw and modified form of DP waste for the extraction of $\mathrm{Cu}^{2+}$ from the aqueous solution. The use of the raw or even modified DP waste, however, for the treatment wastewater on the large scales, for example, industrial scale, is still a concern owing to the cost effectiveness, stability issues, availability and extremely large-scale requirement for DP waste. However, it is evident from the literature that the raw material of
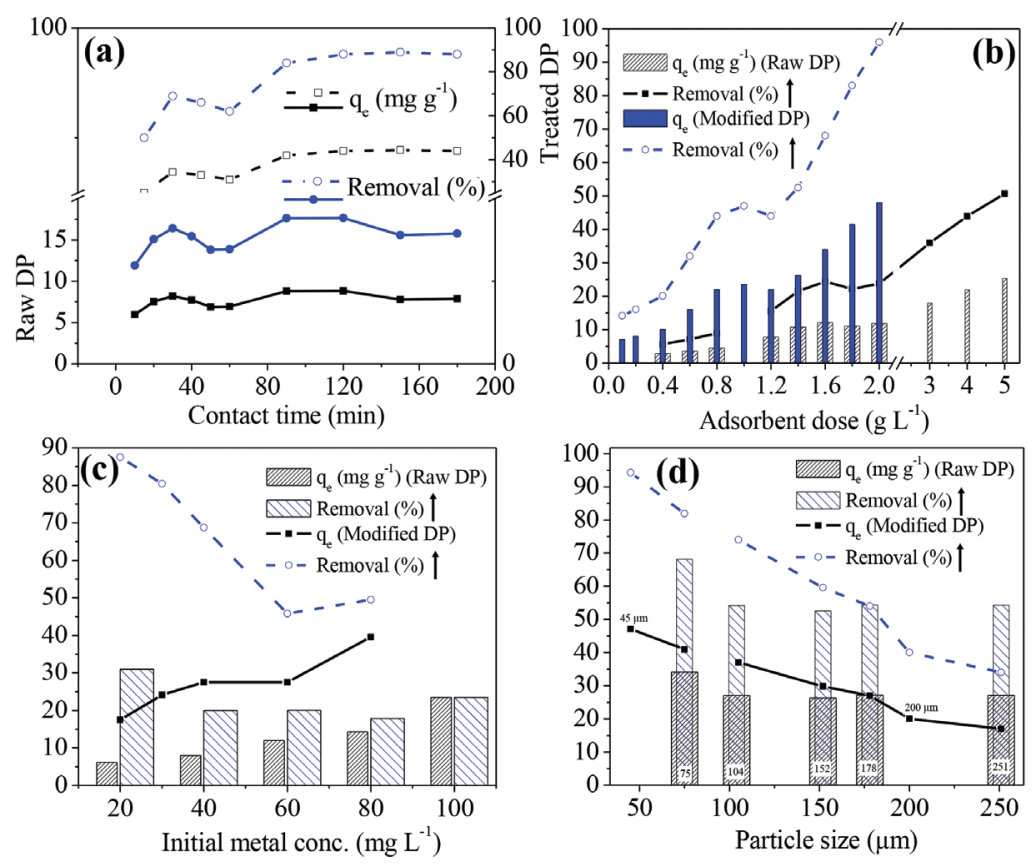

FIGURE 8. Comparison of the raw and modified form of DP waste for the adsorption capacity and percentage removal of $\mathrm{Cu}^{2+}$ (Amin et al. 2016) 
DP has less adsorption capacity than the chemically or physically activated variants. The chemical activation of biosorbents, in contrast, is not favorable because it will make the technology less eco-friendly and costlier. Thus, further studies should be conducted to improve the adsorption potential of the DPraw material using easy and cost-effective techniques, such as using DP waste in the form of dehydrated carbon or in the form of media filters. DP waste leaves could be the potential source to produce dehydrated carbon, a greener alternative to AC, which can be used in wastewater treatment on industrial scale. The production of $\mathrm{AC}$ is a polluting process, as it is usually derived from charcoal and requires the use of high temperature. However, dehydrated carbon can be prepared simply by the treatment of DP leaves with sulfuric acid at $170^{\circ} \mathrm{C}$ before being used to treat wastewater. This technique can be very useful in countries where DP is grown abundantly, especially in Saudi Arabia, where 480,000 tons of DP waste, mostly containing leaves, is produced annually. Dehydrated carbon derived from DP leaves is as efficient as AC for the removal of dyes, hospital waste, and heavy metals and can be reused many times.

DP wastes can be used as filtration media for the secondary and tertiary treatments of industrial wastewater. DP filter media has produced promising results compared with sand bed filters and may be preferred owing to its low-density material, higher filtration rate, lower head loss, longer filtration time, and less backwash water usage (Riahi et al.2009). DP fiber is a natural, cheap and environmental friendly material available in bulk quantities and is thrown away as waste after annual trimming operations in DPcultivating countries. DP fiber filters may be a potential commercial technology for the removal of heavy metals and other pollutants from wastewater.

\section{ACKNOWLEDGEMENTS}

This project was funded by the National Plan for Science, Technology and Innovation (MAARIFAH), King Abdulaziz City for Science and Technology, Kingdom of Saudi Arabia,Award Number(11-WAT1875-02). Authors declare no conflict of interest.

\section{REFERENCES}

Abia, A.A., Horsfall, M.J. \& Didi, O. 2004. Studies on the use of agricultural by-product for the removal of trace metals from aqueous solutions. Journal of Applied Sciences and Environmental Management 6(2): 89-95.

Ahmad, F., Daud, W.M.A.W., Ahmad, M.A. \& Radzi, R. 2012. Cocoa (Theobroma cacao) shell-based activated carbon by $\mathrm{CO} 2$ activation in removing of cationic dye from aqueous solution: Kinetics and equilibrium studies. Chemical Engineering Research and Design 90(10): 1480-1490.

Ahmady-Asbchin, S., Andres, Y., Gerente, C. \& Le Cloirec, P. 2009. Natural seaweed waste as sorbent for heavy metal removal from solution. Environmental Technology 30(7): 755-762.

Ahmaruzzaman, M. 2011. Industrial wastes as low-cost potential adsorbents for the treatment of wastewater laden with heavy metals. Advances in Colloid and Interface Science 166(1-2): 36-59.

Ajmal, M., Rao, R.A.K., Ahmad, R. \& Ahmad, J. 2000. Adsorption studies on Citrus reticulata (fruit peel of orange): removal and recovery of $\mathrm{Ni}(\mathrm{II})$ from electroplating wastewater. Journal of Hazardous Materials 79(1-2): 117-131.

Akunwa, N.K., Muhammad, M.N. \& Akunna, J.C. 2014. Treatment of metal-contaminated wastewater: A comparison of low-cost biosorbents. Journal of Environmental Management 146: 517-523.

Al-Ghamdi, A., Altaher, H. \& Omar, W. 2013. Application of date palm trunk fibers as adsorbents for removal of $\mathrm{Cd}^{+2}$ ions from aqueous solutions. Journal of Water Reuse and Desalination 3(1): 47-54.

Al-Ghouti, M.A., Li, J., Salamh, Y., Al-Laqtah, N., Walker, G. \& Ahmad, M.N.M. 2010. Adsorption mechanisms of removing heavy metals and dyes from aqueous solution using date pits solid adsorbent. Journal of Hazardous Materials 176(1-3): 510-520.

Al-Haidary, A.M.A., Zanganah, F.H.H., Al-Azawi, S.R.F., Khalili, F.I. \& Al-Dujaili, A.H. 2011. A study on using date palm fibers and leaf base of palm as adsorbents for $\mathrm{Pb}(\mathrm{II})$ ions from its aqueous solution. Water, Air, \& Soil Pollution 214(1-4): 73-82.

Al-Homaidan, A.A., Al-Houri, H.J., Al-Hazzani, A.A., Elgaaly, G. \& Moubayed, N.M.S. 2014. Biosorption of copper ions from aqueous solutions by Spirulina platensis biomass. Arabian Journal of Chemistry 7(1): 57-62.

Ali, I. 2010a. The quest for active carbon adsorbent substitutes: Inexpensive adsorbents for toxic metal ions removal from wastewater. Separation \& Purification Reviews 39(3-4): 95-171.

Ali, I., Al-Othman, Z.A., Alwarthan, A., Asim, M. \& Khan, T.A. 2013. Removal of arsenic species from water by batch and column operations on bagasse fly ash. Environmental Science and Pollution Research 21(5): 3218-3229.

Al-Kaabi, K., Al-Khanbashi, A. \& Hammami, A. 2005. Date palm fibers as polymeric matrix reinforcement: DPF/polyester composite properties. Polymer Composites 26(5): 604-613.

Al-Rub, F.A.A. 2006. Biosorption of zinc on palm tree leaves: Equilibrium, kinetics, and thermodynamics studies. Separation Science and Technology 41(15): 3499-3515.

Al-Saidi, H.M. 2013. The fast recovery of gold(III) ions from aqueous solutions using raw date pits: Kinetic, thermodynamic and equilibrium studies. Journal of Saudi Chemical Society 20(6): 615-624.

Alshabanat, M., Alsenani, G. \& Almufarij, R. 2013. Removal of crystal violet dye from aqueous solutions onto date palm fiber by adsorption technique. Journal of Chemistry 2013: e210239.

Amin, M.T., Alazba, A.A. \& Shafiq, M. 2016. Adsorption of copper $\left(\mathrm{Cu}^{2+}\right)$ from aqueous solution using date palm trunk fibre: Isotherms and kinetics. Desalination and Water Treatment 57(47): 22454-22466.

Amin, M.T., Alazba, A.A. \& Shafiq, M. 2015. Adsorptive removal of reactive black 5 from wastewater using Bentonite clay: Isotherms, kinetics and thermodynamics. Sustainability 7(11): 15302-15318.

Amuda, O., Amoo, I. \& Ajayi, O. 2006. Performance optimization of coagulant/flocculant in the treatment of wastewater from a beverage industry. Journal of Hazardous Materials 129(13): $69-72$. 
Areco, M.M. \& Dos Santos Afonso, M. 2010. Copper, zinc, cadmium and lead biosorption by Gymnogongrus torulosus: Thermodynamics and kinetics studies. Colloids and Surfaces B: Biointerfaces 81(2): 620-628.

Aydın, H., Bulut, Y. \& Yerlikaya, Ç. 2008. Removal of copper (II) from aqueous solution by adsorption onto low-cost adsorbents. Journal of Environmental Management 87(1): 37-45.

Balasubramanian, N., Kojima, T., Basha, C.A. \& Srinivasakannan, C. 2009. Removal of arsenic from aqueous solution using electrocoagulation. Journal of Hazardous Materials 167(13): 966-969.

Banerjee, S.S., Jayaram, R.V. \& Joshi, M.V. 2003. Removal of nickel(II) and zinc(II) from wastewater using fly ash and impregnated fly ash. Separation Science and Technology 38(5): 1015-1032.

Baral, S.S., Das, S.N., Rath, P. \& Chaudhury, G.R. 2007. Chromium(VI) removal by calcined bauxite. Biochemical Engineering Journal 34(1): 69-75.

Barreveld, W.H. 1993. Date palm products, FAO Agricultural Services Bulletin No. 101, Food and Agriculture Organization of the United Nations, Italy, Rome (http://www.fao.org/ docrep/t0681e/t0681e00.htm).

Belala, Z., Jeguirim, M., Belhachemi, M., Addoun, F. \& Trouvé, G. 2011. Biosorption of copper from aqueous solutions by date stones and palm-trees waste. Environmental Chemistry Letters 9(1): 65-69.

Bhattacharya, A.K., Mandal, S.N. \& Das, S.K. 2006. Adsorption of $\mathrm{Zn}(\mathrm{II})$ from aqueous solution by using different adsorbents. Chemical Engineering Journal 123(1-2): 43-51.

Bilal, M., Shah, J.A., Ashfaq, T., Gardazi, S.M.H., Tahir, A.A., Pervez, A., Haroon, H. \& Mahmood, Q. 2013. Waste biomass adsorbents for copper removal from industrial wastewater - A review. Journal of Hazardous Materials 263: 322-333.

Blöcher, C., Dorda, J., Mavrov, V., Chmiel, H., Lazaridis, N.K. \& Matis, K.A. 2003. Hybrid flotation-membrane filtration process for the removal of heavy metal ions from wastewater. Water Research 37(16): 4018-4026.

Boudrahem, F., Aissani-Benissad, F. \& Soualah, A. 2011. Adsorption of Lead(II) from aqueous solution by using leaves of date trees as an adsorbent. Journal of Chemical \& Engineering Data 56(5): 1804-1812.

Bouhamed,F., Elouear,Z.\& Bouzid, J. 2012. Adsorptive removal of copper(II) from aqueous solutions on activated carbon prepared from Tunisian date stones: Equilibrium, kinetics and thermodynamics. Journal of the Taiwan Institute of Chemical Engineers 43(5): 741-749.

Brusick, D. 1993. Genotoxicity of phenolic antioxidants. Toxicology and Industrial Health 9(1-2): 223-230.

Bsoul, A.A., Zeatoun, L., Abdelhay, A. \& Chiha, M. 2014. Adsorption of copper ions from water by different types of natural seed materials. Desalination and Water Treatment 52(31-33): 5876-5882.

Bulut, Y. \& Tez, Z. 2007. Adsorption studies on ground shells of hazelnut and almond. Journal of Hazardous Materials 149(1): 35-41.

Chaouch, N., Ouahrani, M. \& Laouini, S. 2014. Adsorption of Lead (II) from aqueous solutions onto activated carbon prepared from Algerian dates stones of Phoenix dactylifera. L (Ghars variety) by H3PO4 activation. Oriental Journal of Chemistry 30(3): 1317-1322.

Chaouch, N., Ouahrani, M.R., Chaouch, S. \& Gherraf, N. 2013. Adsorption of cadmium (II) from aqueous solutions by activated carbon produced from Algerian dates stones of Phoenix dactylifera by $\mathrm{H}_{3} \mathrm{PO}_{4}$ activation. Desalination and Water Treatment 51(10-12): 2087-2092.

Chatterjee, A., Widick, P., Sternschein, R., Smith, W.B. \& Bromberger, B. 2010. The assessment of art attributes. Empirical Studies of the Arts 28(2): 207-222.

Chieng, H.I., Lim, L.B.L. \& Priyantha, N. 2015. Enhancing adsorption capacity of toxic malachite green dye through chemically modified breadnut peel: Equilibrium, thermodynamics, kinetics and regeneration studies. Environmental Technology 36(1): 86-97.

Da browski, A., Hubicki, Z., Podkościelny, P. \& Robens, E. 2004. Selective removal of the heavy metal ions from waters and industrial wastewaters by ion-exchange method. Chemosphere 56(2): 91-106.

Demirbas, A. 2008. Heavy metal adsorption onto agro-based waste materials: A review. Journal of Hazardous Materials 157(2): 220-229.

Dich, J.,Zahm, S.H., Hanberg, A. \& Adami, H.O. 1997. Pesticides and cancer. Cancer Causes \& Control 8(3): 420-443.

Ebrahimi, R., Maleki, A., Shahmoradi, B., Daraei, H., Mahvi, A.H., Barati, A.H. \& Eslami,A. 2013. Elimination of arsenic contamination from water using chemically modified wheat straw. Desalination and Water Treatment 51(10-12): 23062316.

El Nemr, A., Khaled, A., Abdelwahab, O \& \& El-Sikaily, A. 2008. Treatment of wastewater containing toxic chromium using new activated carbon developed from date palm seed. Journal of Hazardous Materials 152(1): 263-275.

El-Bindary, A.A., Hussien, M.A., Diab, M.A. \& Eessa, A.M. 2014. Adsorption of acid yellow 99 by polyacrylonitrile/ activated carbon composite: Kinetics, thermodynamics and isotherm studies. Journal of Molecular Liquids 197: 236-242.

El-Juhany, L.I. 2010. Degradation of date palm trees and date production in Arab countries: Causes and potential rehabilitation. Australian Journal of Basic and Applied Sciences 4(8): 3998-4010.

Ghorbani, F., Sanati, A.M., Younesi, H. \& Ghoreyshi, A.A. 2012. The potential of date palm leaf ash as low cost adsorbent for the removal of $\mathrm{PB}(\mathrm{II})$ ion from aqueous solution. International Journal of Engineering - Transactions B: Applications 25(4): 278-296.

Gupta, V.K., Ali, I., Saleh, T.A., Nayak, A. \& Agarwal, S. 2012. Chemical treatment technologies for waste-water recycling - An overview. RSC Advances 2(16): 6380-6388.

Gupta, V.K., Ali, I., Saleh, T.A., Siddiqui, M.N. \& Agarwal, S. 2013. Chromium removal from water by activated carbon developed from waste rubber tires. Environmental Science and Pollution Research 20(3): 1261-1268.

Haleem, A.M. \& Abdulgafoor, E.A. 2010. The biosorption of Cr (VI) from aqueous solution using date palm fibers (Leef). Al-Khwarizmi Engineering Journal 6(4): 31-36.

Hall, D.W., Sandrin, J.A. \& McBride, R.E. 1990. An overview of solvent extraction treatment technologies. Environmental Progress 9(2): 98-105.

Hamouche, A., Zine, B.M. \& Krim, L. 2015. Kinetics and thermodynamics of $\mathrm{Cr}$ ions sorption on mixed sorbents prepared from olive stone and date pit from aqueous solution. International Journal of Food and Biosystem Engineering 1(1): $1-8$.

He, J. \& Chen, J.P. 2014. A comprehensive review on biosorption of heavy metals by algal biomass: Materials, performances, chemistry, and modeling simulation tools. Bioresource Technology 160: 67-78. 
Hikmat, N.A.,Qassim,B.B.\& Khethi,M.T.2014.Thermodynamic and kinetic studies of lead adsorption from aquesous solution onto petiole and fiber of palm tree. American Journal of Chemistry 4(4): 116-124.

Hilal, N.M., Ahmed, I.A. \& El-Sayed, R.E. 2012. Activated and non-activated date pits adsorbents for the removal of copper(II) and cadmium(II) from aqueous solutions. ISRN Physical Chemistry 2012: 1-11.

Ho, Y.S., Porter, J.F. \& McKay, G. 2002. Equilibrium isotherm studies for the sorption of divalent metal ions onto peat: Copper, nickel and lead single component systems. Water, Air, and Soil Pollution 141(1-4): 1-33.

Hossain, M.A., Ngo, H.H., Guo, W.S., Nguyen, T.V. \& Vigneswaran, S. 2014. Performance of cabbage and cauliflower wastes for heavy metals removal. Desalination and Water Treatment 52(4-6): 844-860.

Izhar, S., Chuan, L.Y. \& Ismail, M.H.S. 2014. Removal of boron and arsenic from petrochemical wastewater using zeolite as adsorbent. From Sources to Solution, edited by Aris, A.Z., Tengku Ismail, T.H., Harun, R., Abdullah, A.M. \& Ishak, M.Y. Singapore: Springer. pp. 439-443.

Jacques, R.A., Bernardi, R., Caovila, M., Lima, E.C., Pavan, F.A., Vaghetti, J.C.P. \& Airoldi, C. 2007. Removal of Cu(II), $\mathrm{Fe}(\mathrm{III})$, and $\mathrm{Cr}$ (III) from aqueous solution by aniline grafted silica gel. Separation Science and Technology 42(3): 591-609.

Javaid,A., Bajwa, R., Shafique, U. \& Anwar, J. 2011. Removal of heavy metals by adsorption on Pleurotus ostreatus. Biomass and Bioenergy 35(5): 1675-1682.

Jiménez-Cedillo, M.J., Olguín, M.T., Fall, C. \& Colin-Cruz, A. 2013. As(III) and As(V) sorption on iron-modified non-pyrolyzed and pyrolyzed biomass from Petroselinum crispum (parsley). Journal of Environmental Management 117: 242-252.

Kamari, A., Yusoff, S.N.M., Abdullah, F. \& Putra, W.P. 2014. Biosorptive removal of $\mathrm{Cu}(\mathrm{II}), \mathrm{Ni}(\mathrm{II})$ and $\mathrm{Pb}$ (II) ions from aqueous solutions using coconut dregs residue: Adsorption and characterisation studies. Journal of Environmental Chemical Engineering 2(4): 1912-1919.

Kanawade, S.M. \& Gaikwad, R.W. 2011. Removal of zinc ions from industrial effluent by using cork powder as adsorbent. International Journal of Chemical Engineering and Applications 2(3): 199-201

Khosa, M.A., Wu, J. \& Ullah, A. 2013. Chemical modification, characterization, and application of chicken feathers as novel biosorbents. RSC Advances 3(43): 20800.

Kim, K.H., Keller, A.A. \& Yang, J.K. 2013. Removal of heavy metals from aqueous solution using a novel composite of recycled materials. Colloids and Surfaces A: Physicochemical and Engineering Aspects 425: 6-14.

Krishnan, K.A. \& Anirudhan, T.S. 2003. Removal of cadmium(II) from aqueous solutions by steam-activated sulphurised carbon prepared from sugar-cane bagasse pith: Kinetics and equilibrium studies. Water SA 29(2): 147-156.

Lattuada, R.M., Peralba, M.C.R., Dos Santos, J.H.Z. \& Fisch, A.G. 2014. Peat, rice husk and rice husk carbon as lowcost adsorbents for metals from acidic aqueous solutions. Separation Science and Technology 49(1): 101-111.

Lee, C.K., Low, K.S. \& Chow, S.W. 1996. Chrome sludge as an adsorbent for colour removal. Environmental Technology 17(9): 1023-1028.

Li, M., Cheng, X. \& Guo, H. 2013. Heavy metal removal by biomineralization of urease producing bacteria isolated from soil. International Biodeterioration \& Biodegradation 76: 81-85
Li, W., Zhang, L., Peng, J., Li, N., Zhang, S. \& Guo, S. 2008. Tobacco stems as a low cost adsorbent for the removal of $\mathrm{Pb}$ (II) from wastewater: Equilibrium and kinetic studies. Industrial Crops and Products 28(3): 294-302.

Liang, S., Guo, X., Feng, N. \& Tian, Q. 2009. Application of orange peel xanthate for the adsorption of $\mathrm{Pb} 2+$ from aqueous solutions. Journal of Hazardous Materials 170(1): 425-429.

Lim,A.P.,Aris,A.Z. \& Juahir, H. 2014. An experimental approach on the removal of $\mathrm{Cd}$ (II) and $\mathrm{Pb}$ (II) ions from aqueous solutions by using dead calcareous skeletons. In From Sources to Solution, edited by Aris, A.Z., Tengku Ismail, T.H., Harun, R., Abdullah, A.M. \& Ishak, M.Y. Singapore: Springer. pp. 117-120.

Mallaki, M. \& Fatehi, R. 2014. Design of a biomass power plant for burning date palm waste to cogenerate electricity and distilled water. Renewable Energy 63(C): 286-291.

Mandal, N.K. 2014. Performance of low-cost bio adsorbents for the removal of metal ions - A review. International Journal of Science and Research 3(1): 177-180.

Marin, A.B.P., Ortuno, J.F., Aguilar, M.I., Meseguer, V.F., Saez, J. \& Llorens, M. 2010. Use of chemical modification to determine the binding of $\mathrm{Cd}(\mathrm{II}), \mathrm{Zn}(\mathrm{II})$ and $\mathrm{Cr}(\mathrm{III})$ ions by orange waste. Biochemical Engineering Journal 53(1): 2-6.

Mavrov, V., Stamenov, S., Todorova, E., Chmiel, H. \& Erwe, T 2006. New hybrid electrocoagulation membrane process for removing selenium from industrial wastewater. Desalination 201(1-3): 290-296.

Mohan, D. \& Pittman, C.U. 2007. Arsenic removal from water/ wastewater using adsorbents - A critical review. Journal of Hazardous Materials 142(1-2): 1-53.

Mohan, S. \& Gandhimathi, R. 2009. Removal of heavy metal ions from municipal solid waste leachate using coal fly ash as an adsorbent. Journal of Hazardous Materials 169(1-3): 351-359.

Momcilovic, M., Purenovic, M., Bojic, A., Zarubica, A. \& Ranđelovic, M. 2011. Removal of lead(II) ions from aqueous solutions by adsorption onto pine cone activated carbon. Desalination 276(1-3): 53-59.

Moore, J.W. \& Ramamoorthy, S. 1984. Heavy Metals in Natural Waters: Applied Monitoring and Impact Assessment. New York: Springer. pp.77-99. http://link. springer.com/10.1007/978-1-4612-5210-8_5.

Muhammad, M.N. \& Nwaedozie, J.M. 2012. Application of marine biomass for the removal of metals from industrial wastewater. Indian Journal of Innovations and Development 1(1): 36-44.

Namasivayam, C. \& Senthilkumar, S. 1999. Adsorption of copper(II) by "waste" $\mathrm{Fe}(\mathrm{III}) / \mathrm{Cr}$ (III) hydroxide from aqueous solution and radiator manufacturing industry wastewater. Separation Science and Technology 34(2): 201-217.

Narain, S., Ojha, C.S.P., Mishra, S.K., Chaube, U.C. \& Sharma, P.K. 2011. Cadmium and chromium removal by aquatic plant. International Journal of Environmental Sciences 1(6): 1297-1304.

Olaofe, O., Olagboye, S.A., Akanji, P.S., Adamolugbe, E.Y., Fowowe, O.T. \& Olaniyi, A.A. 2015. Kinetic studies of adsorption of heavy metals on clays. International Journal of Chemistry 7(1): 48-54.

Oller, I., Malato, S. \& Sánchez-Pérez, J.A. 2011. Combination of advanced oxidation processes and biological treatments for wastewater decontamination - A review. Science of the Total Environment 409(20): 4141-4166. 
Opeolu, B.O., Bamgbose, O., Arowolo, T.A. \& Adetunji, M.T. 2010. Utilization of biomaterials as adsorbents for heavy metals' removal from aqueous matrices. Scientific Research and Essays 5(14): 1780-1787.

Paez-Hernandez, M.E., Aguilar-Arteaga, K., Galan-Vidal, C.A., Palomar-Pardave, M., Romero-Romo, M. \& Ramirez-Silva, M.T. 2005. Mercury ions removal from aqueous solution using an activated composite membrane. Environmental Science \& Technology 39(19): 7667-7670.

Park, D., Yun, Y.S. \& Park, J.M. 2010. The past, present, and future trends of biosorption. Biotechnology and Bioprocess Engineering 15(1): 86-102.

Pehlivan, E., Tran, H.T., Ouédraogo, W.K.I., Schmidt, C., Zachmann, D. \& Bahadir, M. 2013. Sugarcane bagasse treated with hydrous ferric oxide as a potential adsorbent for the removal of $\mathrm{As}(\mathrm{V})$ from aqueous solutions. Food Chemistry 138(1): 133-138.

Purkayastha, D., Mishra, U. \& Biswas, S. 2014. A comprehensive review on Cd(II) removal from aqueous solution. Journal of Water Process Engineering 2: 105-128.

Putra, W.P., Kamari, A., Yusoff, S.N.M., Ishak, C.F., Mohamed, A., Hashim, N. \& Isa, I.M. 2014. Biosorption of Cu(II), Pb(II) and $\mathrm{Zn}(\mathrm{II})$ ions from aqueous solutions using selected waste materials: Adsorption and characterisation studies. Journal of Encapsulation and Adsorption Sciences 04(01): 25-35.

Qadeer, R. \& Akhtar, S. 2005. Kinetics study of lead ion adsorption on active carbon. Turk. J. Chem. 29: 95-99.

Qian, F., Sun, X., Liu, Y. \& Xu, H. 2013. Removal and transformation of effluent organic matter (EfOM) in biotreated textile wastewater by $\mathrm{GAC} / \mathrm{O} 3$ pre-oxidation and enhanced coagulation. Environmental Technology 34(12): 1513-1520.

Rajamohan, N., Rajasimman, M. \& Dilipkumar, M. 2014. Parametric and kinetic studies on biosorption of mercury using modified Phoenix dactylifera biomass. Journal of the Taiwan Institute of Chemical Engineers 45(5): 2622-2627.

Rathinam, A., Maharshi, B., Janardhanan, S.K., Jonnalagadda, R.R. \& Nair, B.U. 2010. Biosorption of cadmium metal ion from simulated wastewaters using Hypnea valentiae biomass: A kinetic and thermodynamic study. Bioresource Technology 101(5): 1466-1470.

Ratna Kumar, P., Chaudhari, S., Khilar, K.C. \& Mahajan, S.P. 2004. Removal of arsenic from water by electrocoagulation. Chemosphere 55(9): 1245-1252.

Renge, V.C., Khedkar, S.V. \& Pande, S.V. 2012. Removal of heavy metals from waste water using low cost adsorbents: A review. Scientific Reviews \& Chemical Communications 2(4): 580-584.

Riahi, K., Mammou,A.B.\& Thayer, B.B. 2009. Date-palm fibers media filters as a potential technology for tertiary domestic wastewater treatment. Journal of Hazardous Materials 161(2-3): 608-613.

Riaz, M., Nadeem, R., Hanif, M.A., Ansari, T.M. \& Rehman, K. 2009. $\mathrm{Pb}(\mathrm{II})$ biosorption from hazardous aqueous streams using Gossypium hirsutum (Cotton) waste biomass. Journal of Hazardous Materials 161(1): 88-94.

Sahu, M.K., Mandal, S., Dash, S.S., Badhai, P. \& Patel, R.K. 2013. Removal of $\mathrm{Pb}$ (II) from aqueous solution by acid activated red mud. Journal of Environmental Chemical Engineering 1(4): 1315-1324.

Saka, C., Şahin, Ö. \& Küçük, M.M. 2012. Applications on agricultural and forest waste adsorbents for the removal of lead (II) from contaminated waters. International Journal of Environmental Science and Technology 9(2): 379-394.
Sankararamakrishnan, N., Jaiswal, M. \& Verma, N. 2014. Composite nanofloral clusters of carbon nanotubes and activated alumina: An efficient sorbent for heavy metal removal. Chemical Engineering Journal 235: 1-9.

Sciban, M., Radetic, B., Kevresan, Z. \& Klasnja, M. 2007. Adsorption of heavy metals from electroplating wastewater by wood sawdust. Bioresource Technology 98(2): 402-409.

Sha, L., Xueyi, G., Ningchuan, F. \& Qinghua, T. 2009. Adsorption of $\mathrm{Cu} 2+$ and $\mathrm{Cd} 2+$ from aqueous solution by mercaptoacetic acid modified orange peel. Colloids and Surfaces B: Biointerfaces 73(1): 10-14.

Shahzad, A., Miran, W., Rasool, K., Nawaz, M., Jang, J., Lim, S.R. \& Lee, D.S. 2017. Heavy metals removal by EDTAfunctionalized chitosan graphene oxide nanocomposites. RSC Advances 7(16): 9764-9771.

Shakoor, M.B., Niazi, N.K., Bibi, I., Murtaza, G., Kunhikrishnan, A., Seshadri, B., Shahid, M., Ali, S., Bolan, N.S., Ok, Y.S., Abid, M. \& Ali, F. 2016. Remediation of arseniccontaminated water using agricultural wastes as biosorbents. Critical Reviews in Environmental Science and Technology 46(5): 467-499.

Shyam, R., Puri, J.K., Kaur, H., Amutha, R. \& Kapila, A. 2013. Single and binary adsorption of heavy metals on fly ash samples from aqueous solution. Journal of Molecular Liquids 178: 31-36.

Singh, U. \& Kaushal, R.K. 2013. Treatment of waste water with low cost adsorbent - A review. VSRD International Journal of Technical \& Non-Technical Research 4(13): 33-42.

Sočo, E. \& Kalembkiewicz, J. 2013. Adsorption of nickel(II) and copper(II) ions from aqueous solution by coal fly ash. Journal of Environmental Chemical Engineering 1(3): 581-588.

Soliman, A.M., Elwy, H.M., Thiemann, T., Majedi, Y., Labata, F.T. \& Al-Rawashdeh, N.A.F. 2016. Removal of Pb(II) ions from aqueous solutions by sulphuric acid-treated palm tree leaves. Journal of the Taiwan Institute of Chemical Engineers 58: 264-273.

Srivastav, R.K., Gupta, S.K., Nigam, K.D.P. \& Vasudevan, P. 1993. Use of aquatic plants for the removal of heavy metals from wastewater. International Journal of Environmental Studies 45(1): 43-50.

Srivastava, S.K., Singh, A.K. \& Sharma, A. 1994. Studies on the uptake of lead and zinc by lignin obtained from black liquor - a paper industry waste material. Environmental Technology 15(4): 353-361.

Tan, G. \& Xiao, D. 2009. Adsorption of cadmium ion from aqueous solution by ground wheat stems. Journal of Hazardous Materials 164(2-3): 1359-1363.

Tan, W.T. 1985. Copper (II) adsorption by waste tea leaves and coffee powder. Pertanika 8(2): 223-230.

UN WWAP 2003. United Nations World Water Assessment Programme. The World Water Development Report 1: Water for People, Water for Life. UNESCO: Paris, France.

Uzunoğlu, D., Gürel, N., Özkaya, N.\& Özer, A. 2014. The single batch biosorption of copper(II) ions on Sargassum acinarum. Desalination and Water Treatment 52(7-9): 1514-1523.

Varga, M., Takacs, M., Zaray, G. \& Varga, I. 2013. Comparative study of sorption kinetics and equilibrium of chromium (VI) on charcoals prepared from different low-cost materials. Microchemical Journal 107: 25-30.

Wang, S. \& Peng, Y. 2010. Natural zeolites as effective adsorbents in water and wastewater treatment. Chemical Engineering Journal 156(1): 11-24. 
WHO 2011. Guidelines for drinking-water quality, World Health Organization, 20 Avenue Appia, 1211 Geneva 27, Switzerland (http://www.who.int/water_sanitation_health/ publications/2011/dwq_guidelines/en/).

Yacob,A.R., Mustapha, N.M.,Ali, A. \& Al Swaidan, H.M. 2013. One-step air pyrolysis of date palm tree waste: Physical and morphological study. Journal of Biobased Materials and Bioenergy 7(2): 223-228.

Yadav, S.K., Singh, D.K. \& Sinha, S. 2013. Adsorption study of lead(II) onto xanthated date palm trunk: Kinetics, isotherm and mechanism. Desalination and Water Treatment 51(3436): 6798-6807.

Yadav, S.K., Sinha, S. \& Singh, D.K. 2015. Chromium(VI) removal from aqueous solution and industrial wastewater by modified date palm trunk. Environmental Progress \& Sustainable Energy 34(2): 452-460.

Zahra, N. 2012. Lead removal from water by low cost adsorbents: a review. Pak. J. Anal. Environ. Chem. 13(1): 01-08.

Zhang, H., Xiang, L., Zhang, D. \& Qing, H. 2012. Treatment of landfill leachate by internal microelectrolysis and sequent Fenton process. Desalination and Water Treatment 47(1-3): 243-248.

Zhu, B., Fan, T. \& Zhang, D. 2008. Adsorption of copper ions from aqueous solution by citric acid modified soybean straw. Journal of Hazardous Materials 153(1-2): 300-308.

Zwain, H.M., Vakili, M. \& Dahlan, I. 2014. Waste material adsorbents for zinc removal from wastewater: A comprehensive review. International Journal of Chemical Engineering 2014: 1-13.
M. Shafiq, A.A. Alazba \& M.T. Amin*

Alamoudi Water Research Chair

King Saud University

P. O. Box 2460, Riyadh 11451

Kingdom of Saudi Arabia

A.A. Alazba

Agricultural Engineering Department

King Saud University

P. O. Box 2460, Riyadh 11451

Kingdom of Saudi Arabia

M.T. Amin*

Departmzent of Environmental Sciences

COMSATS Institute of Information Technology

Abbottabad, 22060

Pakistan

*Corresponding author; email: mtamin@ksu.edu.sa

Received: 12 March 2017

Accepted: 26 June 2017 